\title{
Investigation of self confidence levels in elite extreme athletes
}

\author{
Bostanc1 Ö. ${ }^{\mathrm{ABCDE}}$, Karaduman E. ${ }^{\mathrm{ABCDE}}$, Mayda M.H. ${ }^{\mathrm{ABCDE}}$ \\ Yaşar Doğu Faculty of Sports Sciences, Ondokuz Mayls University, Samsun, Turkey
}

Authors' Contribution: A - Study design; B - Data collection; C - Statistical analysis; D - Manuscript Preparation; E - Funds Collection.

\begin{abstract}
Purpose: $\quad$ The purpose of this study is to examine self-confidence levels of extreme sports athletes in terms of variables such as gender, sport experience and sports level.

Material: $\quad$ A total of 1660 athletes in skiing, snowboarding, mountaineering, motor-car and motor-bike racing participated in the study. "Self-confidence scale" developed by Akın (2007) was used to find out athletes' characteristics of self-belief, being able to control emotions and taking risks. Mann Whitney $U$ and Kruskal Wallis test were used for data analysis.

Results: $\quad$ Skiers and motor-car racers were found to have the highest self-confidence values, while snowboarders had the lowest values. Although there were less women in the study, significance was found only in external selfconfidence in favour of women $(p<0.05)$. Significant association was found between self-confidence values in terms of sport experience and sports level $(p<0.05)$.

Conclusions: Extreme sports should be generalized, supported and introduced to raise successful and self-confident individuals. This will contribute to the fast development of these sports which are known as dangerous sports throughout the world.

Keywords: confidence, extreme sport, taking risk, athlete, competition.
\end{abstract}

\section{Introduction}

Studies have been conducted to find out factors influencing participation in sport $[1,2]$ and physical activities [3] from past to present [4, 5]. There are different motives stimulating the inner power of individuals according to their needs. Some of these motives are letting off steam, competence, aesthetic, self-realization, self-confidence, competition, aggression, taking risks and success [6]. One of the psychological factors influencing athletes' high level performance is self-confidence $[7,8]$. White argues that self-confidence leads to increased knowledge, taking risks, thinking positively, being courageous, setting goals, and selfbelief. These in turn influence an individual's success [9]. An individual's having self-confidence and showing his/her skills successfully causes him/her contribute to a happy and positive life [10]. Athletes with high selfconfidence have physical and mental skills that will reveal all their potential to reach success even under risk [8]. In fact, it has been found that such athletes can control their anxiety more easily and focus on positive thoughts. They can also show their calm and relaxed behaviours during a competition when compared with other athletes $[11,12]$.

Sport creates a new environment for the physiological, psychological and social developments of contemporary human beings and presents solutions [13]. Psychological satisfaction of individuals, desire for adrenalin, search for emotion and desire for adventure create new sports which push the limits all the time. Such desires of individuals have increased the interest for extreme sports since the last two decades [14].

Studies have shown these sports (mountaineering $[15,16]$, skiing, snowboarding, motor-car and motorbike racing [17] can cause serious injuries and deaths.

() Bostancı Ö., Karaduman E., Mayda M.H., 2019

doi:10.15561/20755279.2019.0301
They are also shown to include high levels of risk [18, 19]. Zuckerman defines individuals doing risky sportive activities as high level thrill-seekers [20, 21]. The basic characteristics differentiating extreme sports from other sports are thrill-seeking, high risk, concentration, contest and adventure [22, 23]. Traditional sports reflect values such as cooperation, team work and group struggle. On the contrary, extreme sports include intense individuality, marginality, challenge and aggression to some extent [24, 25]. Extreme athletes with a high ability of overcoming the fear of being hurt or dying [26] can take higher rates of risks. They do this to show their abilities to viewers [27]. The feeling underlying extreme sports includes intense fear. However, the athlete tries to take control of the fear instead of letting the fear take control of the situation. Despite these intense fears, it has been understood that the athlete's wish to realize the activity takes him/her to a greater search of the self [28]. It is known that there is a relationship between individuals' desire for adrenalin and their participation in extreme sports [29]. The aim of the present study is to find out self-confidence levels of elite extreme athletes in terms of their branches.

\section{Material and methods}

\section{Participants}

1660 Turkish elite athletes in skiing $(\mathrm{n}=200)$, snowboarding $(\mathrm{n}=44)$, mountaineering $(\mathrm{n}=550)$, motor-car $(n=298)$ and motor-bike racing $(n=568)$ participated in the study. Average age of the participants was $27.91 \pm 10.66$.

\section{Data Collection}

All the participants filled in demographic information questionnaire and self-confidence scale developed by Akın [30]. The data were collected in person from skiers and mountaineers who participated in Turkish championships and training camps in 2016-2017 season. 
Data were collected from motor-car athletes through Turkish Automobile Sport Federation and through digital environment from motor-bike racing athletes.

Self-confidence Scale

Internal consistency coefficient of the self-confidence scale was found as .83 for the whole scale by Akın [30]. Internal consistency coefficients of the internal and external self-confidence were found as .83 and .85 , respectively. $1^{\text {st }}, 3^{\text {rd }}, 4^{\text {th }}, 5^{\text {th }}, 7^{\text {th }}, 9^{\text {th }}, 10^{\text {th }}, 12^{\text {th }}, 15^{\text {th }}, 17^{\text {th }}$, $19^{\text {th }}, 21^{\text {st }}, 23^{\text {rd }}, 25^{\text {th }}, 27^{\text {th }}, 30^{\text {th }}$ and $32^{\text {nd }}$ items form the internal self-confidence dimension. $2^{\text {nd }}, 6^{\text {th }}, 8^{\text {th }}, 11^{\text {th }}, 13^{\text {th }}$, $14^{\text {th }}, 16^{\text {th }}, 18^{\text {th }}, 20^{\text {th }}, 22^{\text {nd }}, 24^{\text {th }}, 26^{\text {th }}, 28^{\text {th }}, 29^{\text {th }}, 31^{\text {st }}$ and $33^{\text {rd }}$ items form the external self-confidence dimension. The items explain $43.6 \%$ of the total variance (Akın, 2007) [30]. Internal self-confidence sub-dimension of the scale explains an individual's beliefs and feelings about selflove and self-knowledge. It also explains individual's beliefs about setting clear goals to self, positive thinking and being pleased with oneself. External self-confidence expresses an individual's image and behaviours about communication, self-expression, controlling feelings and looking assured on the outside. The highest score one can get from the scale is 165 , while the lowest score is 33 . The scale does not have any negative items and higher scores show higher self-confidence. Reliability of the scale was found with Cronbach Alpha coefficient and total reliability of 33 questions was found as .93. The reliability of the internal self-confidence was found as 0.87 , while the reliability of the external self-confidence was found as 0.87 .

Statistical Analysis

Ondokuz Mayıs University licensed SPSS 21.0 program was used for the analysis of data. Normality analysis of the data was conducted with Kolmogorov Smirnov test and it was found that the data were not normally distributed $(\mathrm{p}<0.05)$. Thus, Mann Whitney U test was used for paired comparisons between groups. Kruskal Wallis test was conducted for the comparison of groups of more than two.

\section{Results}

Skiers in the study were found to have higher total scores $(144.50 \pm 15.85 ; 74.04 \pm 8.79 ; 70.47 \pm 7.95$ respectively) when compared with other extreme sports branches. Significant difference was found between branches, in total self-confidence and sub-dimension (internal-external) levels $(\mathrm{p}<0.05)$.

Analysis results showed that there were no differences between athletes' total confidence and internal selfconfidence dimension $(\mathrm{p}>0.05)$. However, a significant

Table 1. Comparison of self-confidence and sub-scales in terms of branches

\begin{tabular}{|c|c|c|c|c|c|c|c|c|c|c|c|c|c|}
\hline \multirow{2}{*}{ Variables } & \multirow[b]{2}{*}{$\mathbf{n}$} & \multicolumn{4}{|c|}{ Self-Confidence } & \multicolumn{4}{|c|}{ Internal Self-Confidence } & \multicolumn{4}{|c|}{ External Self-Confidence } \\
\hline & & $\bar{x}$ & Sd & Med. & Iqr & $\bar{x}$ & Sd & Med. & Iqr & $\bar{x}$ & Sd & Med & Iqr \\
\hline Skiing & 200 & $144.50^{\mathrm{a}}$ & 15.85 & 149.0 & 17.0 & $74.04^{\mathrm{a}}$ & 8.79 & 76.0 & 10.0 & $70.47^{a}$ & 7.95 & 72.0 & 8.75 \\
\hline Snowboarding & 44 & $137.68^{c}$ & 20.55 & 143.0 & 30.0 & $70.86^{b}$ & 9.94 & 72.5 & 15.5 & $66.82^{c}$ & 11.25 & 69.0 & 15.25 \\
\hline Mountaineering & 550 & $140.17^{b c}$ & 16.38 & 141.0 & 22.0 & $72.24^{\mathrm{ab}}$ & 8.67 & 73.0 & 11.0 & $67.93^{b c}$ & 8.44 & 69.0 & 12.0 \\
\hline Motor-car & 298 & $143.71^{\mathrm{ab}}$ & 16.1 & 147.0 & 18.0 & $73.92^{\mathrm{a}}$ & 8.42 & 75.0 & 10.0 & $69.79^{a b}$ & 8.26 & 72.0 & 9.25 \\
\hline \multirow[t]{2}{*}{$\begin{array}{l}\text { Motor-bike } \\
\text { racing }\end{array}$} & 568 & $140.35^{b c}$ & 16.36 & 143.0 & 21.0 & $72.67^{\mathrm{ab}}$ & 8.56 & 74.0 & 11.0 & $67.68^{c}$ & 8.63 & 69.0 & 11.0 \\
\hline & & \multicolumn{4}{|l|}{ p: 0.001} & \multicolumn{4}{|l|}{ p: 0.002} & \multicolumn{4}{|l|}{$\mathrm{p}: 0.001$} \\
\hline
\end{tabular}

Table 2. Comparison of self-confidence and sub-dimensions according to athletes' genders

\begin{tabular}{|c|c|c|c|c|c|c|c|c|c|c|c|c|c|}
\hline \multirow{2}{*}{ Variables } & \multicolumn{4}{|c|}{ Self-Confidence } & \multirow[b]{2}{*}{ Iqr } & \multicolumn{4}{|c|}{ Internal Self-Confidence } & \multicolumn{4}{|c|}{ External Self-Confidence } \\
\hline & 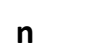 & $\bar{x}$ & Sd & Med. & & $\bar{x}$ & Sd & Med. & Iqr & $\bar{x}$ & Sd & Med & Iqr \\
\hline Female & 312 & 142.83 & 15.47 & 146.0 & 17.75 & 73.03 & 8.23 & 74.0 & 10.0 & 69.8 & 8.0 & 71.0 & 10.0 \\
\hline \multirow[t]{2}{*}{ Male } & 1348 & 140.97 & 16.67 & 143.0 & 21.00 & 72.83 & 8.76 & 74.0 & 11.0 & 68.14 & 8.66 & 70.0 & 12.0 \\
\hline & & \multicolumn{4}{|l|}{ p: 0.091} & \multicolumn{4}{|c|}{$\mathrm{p}: 0.953$} & \multicolumn{4}{|c|}{$\mathrm{p}: 0.001$} \\
\hline
\end{tabular}

Table 3. Comparison of self-confidence and sub-dimensions according to athletes' sport experience

\begin{tabular}{|c|c|c|c|c|c|c|c|c|c|c|c|c|c|}
\hline \multirow{2}{*}{ Variables } & \multirow[b]{2}{*}{$\mathbf{n}$} & \multicolumn{4}{|c|}{ Self-Confidence } & \multicolumn{4}{|c|}{ Internal Self-Confidence } & \multicolumn{4}{|c|}{ External Self-Confidence } \\
\hline & & $\bar{x}$ & Sd & Med. & Iqr & $\bar{x}$ & Sd & Med. & Iqr & $\bar{X}$ & Sd & Med & Iqr \\
\hline $0-4$ & 682 & $138.96^{c}$ & 16.29 & 141.0 & 23.0 & $71.62^{c}$ & 8.58 & 73.0 & 12.0 & $67.34^{\mathrm{b}}$ & 8.51 & 68.0 & 12.0 \\
\hline $5-6$ & 239 & $141.26^{b c}$ & 16.4 & 145.0 & 18.0 & $72.79^{b c}$ & 8.89 & 74.0 & 10.0 & $68.46^{\mathrm{ab}}$ & 8.24 & 70.0 & 10.0 \\
\hline $7-8$ & 247 & $142.41^{\mathrm{a}}$ & 14.98 & 145.0 & 18.0 & $73.30^{\mathrm{ab}}$ & 7.75 & 75.0 & 10.0 & $69.11^{\mathrm{a}}$ & 8.0 & 71.0 & 10.0 \\
\hline $9-10$ & 156 & $143.05^{a b}$ & 17.45 & 146.5 & 20.0 & $73.79^{\mathrm{ab}}$ & 8.77 & 74.5 & 10.0 & $69.26^{\mathrm{a}}$ & 9.4 & 72.0 & 9.75 \\
\hline 10 and high & 336 & $144.57^{a}$ & 16.78 & 148.0 & 19.0 & $74.72^{\mathrm{a}}$ & 8.89 & 76.5 & 11.0 & $69.85^{\mathrm{a}}$ & 8.64 & 72.0 & 10.75 \\
\hline
\end{tabular}

$p<0.001$ 
Table 4. Comparison of self-confidence and sub-dimensions according to athletes' sport level

\begin{tabular}{lllllllllllllll}
\hline \multirow{2}{*}{ Variables } & \multicolumn{4}{c}{ Self-Confidence } & \multicolumn{4}{c}{ Internal Self-Confidence } & \multicolumn{3}{c}{ External Self-Confidence } \\
& $\mathbf{n}$ & $\bar{X}$ & Sd & Med. & Iqr & $\bar{X}$ & Sd & Med. & Iqr & $\bar{X}$ & Sd & Med & Iqr & \\
\hline International & 222 & 144.46 & 16.25 & 148.0 & 19.5 & 74.45 & 8.58 & 76.0 & 10.25 & 70.0 & 8.35 & 72.5 & 10.25 \\
National & 1438 & 140.84 & 16.45 & 143.0 & 20.25 & 72.62 & 8.65 & 74.0 & 11.0 & 68.21 & 8.57 & 70.0 & 12.0 \\
\hline
\end{tabular}

p: 0.001

difference was found in external self-confidence $(69.8 \pm 8.0)$ in favour of women $(\mathrm{p}<0.05)$.

When table three is examined, it can be seen that as the related sport experience increases, self-confidence is also increased $(\mathrm{p}<0.05)$.

The athletes on the national team in their branches had higher total $(144.46 \pm 16.25)$, internal $(74.45 \pm 8.58)$ and external self-confidence $(70.0 \pm 8.35)$ levels.

\section{Discussion}

Individuals who are inclined to extreme sports [31, 32] choose sport branches which give them pleasure, entertain them and push their limits [33-35]. Number of studies which aim to find out psychological states of extreme sports athletes rather than their physical characteristics have increased [36-38]. As a result of the study, it was found that skiers $(144.5 \pm 15.85)$ and motor-car athletes $(143.71 \pm 16.1)$ had higher self-confidence rates when compared with other athletes $(\mathrm{p}<0.05)$. Values which make up the characteristics of extreme sports consist of speed, acceleration, changing direction, pushing limits, risk and internal thrill [33]. Literature review on the subject showed that there are no academic studies in literature about the self-confidence of extreme sports athletes. Having technique, courage, speed, balance, risk and condition to keep up with competition in different weather, altitude and tough pitched tracks is not easy. They can only be done by athletes who have high levels of self-confidence. This is supported by the aforementioned result.

In the sub-dimension of external self-confidence, women $(69.8 \pm 8.0)$ participants were found to have higher values than men $(68.14 \pm 8.66)(\mathrm{p}<0.05)$. However, no difference was found between internal and total selfconfidence $(p>0.05)$. It was found that gender had an influence on self-confidence and performance of athletes [39-41]. Some studies showed higher self-confidence in women $[42,43]$ and others showed higher self-confidence in men [44-46]. It can be said that women athletes in almost every branch of sport today always try to keep their self-confidence and potentials high. They also focus on developing these to adapt to the nature of the sports that they are doing and to keep their identity.

In sport, experience influences performance directly $[9,47,48]$. In the present study, athletes with a sportive experience of 10 years and more $(144.57 \pm 16.78)$ had the highest level of self-confidence $(p<0.05)$. Self-confidence levels which increased directly proportionally to the time of their sport experience can be explained as the increasing levels of self-confidence resulting from experiences. The results of Perry and William's [49] study on tennis players and Karagun's [43] study on different sport branches support our findings. Recently, world records are broken with regular intervals and it is known that this results from experiences in sport [50-52]. Various studies have shown that there is a consistent association between performance and time spent. At the same time, it has been shown that 10 years rule is necessary to have international success in sports [53]. Developed, elite, experienced athletes have higher self-confidence when compared with amateur athletes who do not have international experience [54, 55]. Table 4 shows that athletes who represent their countries in international competitions have higher selfconfidence levels than those who do not $(\mathrm{p}<0.05)$. Bull et al. [54] and Jones et al. [57] conducted a study on elite athletes of international level. They argued that the most critical mental skill in finding out mental endurance is self-confidence. Mahoney et al. [58] found that selfconfidence did not cause a difference between elite athletes. However, elite athletes had higher and fixed rates when compared with non-elite athletes. Choosing athletes with technical and tactical integrity and high levels of self-confidence in national teams will have a direct influence on success. Future studies can focus on different cases, such as impulsive, hedonists, lack of selfcontrol, neuroticism, different personality types. For this reason, extra version may lead to increases on success and decreases of risk-taking behaviours, which illustrates the complexity of traits. Impulsivity may play an important role in this context, influence their performance, engage in risk-taking behaviours.

\section{Conclusion}

As a conclusion, this study examined the selfconfidence of individuals doing extreme sports in different branches. The results showed that skiers and car racers had the highest values. In addition, it was found that different characteristics (gender, sport experience, sports level) influenced their self-confidence in high levels. When the association between athletes' individual characteristics and their self-confidence was examined, significance was found in almost all external self-confidence factors. This result is thought to occur due to social interaction, selfrealization, social responsibility, reassurance and social power on the basis of such sports. Another reason for this result is the interaction with the environment in such sports when compared with other sports branches. However, these branches extreme sports participants are actively 
engaged in may not have a phenomenon which shows the same characteristic of the branches. Thus, future studies can focus on different branches and different cases. It is suggested that self-confidence should be researched on different extreme sport branches. In addition, athletes' self-confidence should be regularly checked according to competition days, especially for sustainable success.
Lastly, the subject of self-confidence should be covered in training plans.

\section{Financial support}

There is no financial support.

\section{Conflict of interest}

The authors declare no conflict of interest.

\section{References}

1. Gould D, Feltz D, Weiss MR. Motives for participating in competitive youth swimming. International Journal of Sport Psychology, 1985; 16(2): 126-140.

2. Gill DL, Gross JB, Huddleston S. Participation motivation in youth sport. International Journal of Sport Psychology, 1983; 14: 1-14.

3. Wankel LM. The importance of enjoyment to adherence and psychological benefits from physical activity. International Journal of Sport Psychology, 1993; 24: 151-169.

4. Koivula N. Sports participation: Differences in motivation and actual participation due to gender typing. Journal of Sport Behavior, 1999; 22: 360-376.

5. Ko YJ, Park H, Claussen CL. Action sports participation: Consumer motivation. International Journal of Sports Marketing and Sponsorship, 2008; 9(2): 111-124.

6. Milne GR, Mcdonald MA. Motivation of sport consumer in sport marketing: Managing the exchange process. Sudbury, MA. : Jones and Bartlett Publisher; 1999. p. 21-38.

7. Feltz DL. Self confidence and sport performance. Exercise and Sports Science Reviews, 1988; 16: 423- 458. https://doi.org/10.1249/00003677-198800160-00016

8. Y1ldırım F. Adaptation of sport trait self-confidence subscale and studying sports trait self confidence in various variables on high school students. [Master Thesi]. Mersin University Institute of Educational Sciences, Department of Physical Education and Sports; 2013.

9. White KA. Self-confidence, a concept analysis. Nursing Forum, 2009; 44(3): 103- 114. https://doi.org/10.1111/j.1744-6198.2009.00133.x

10.Ekinci $H$. The investigation self-reliance perceptions releated to soloist stage performance of music teacher candidates according to variables. Mehmet Akif Ersoy University Journal of Educational Sciences Institute, 2013; 2(2): 52-64.

11.Jones G, Swain ABJ. Predispositions to experience debilitative and facilitative anxiety in elite and nonelite performers. The Sport Psychologist, 1995; 9: 202- 212. https://doi.org/10.1123/tsp.9.2.201

12.Tutko T, Tosi U. Sports psyching: Playing your best game all of the time. New York: Putnam Publishing; 1976.

13.Salar B, Hekim M, Tokgoz M. To compare emotional state of individuals making team and individual sport 15-18 age group. Mehmet Akif Ersoy University Journal of Social Sciences Institute, 2012; 4(6): 123-135.

14.Pain MTG, Pain MA. Essay; Risk taking in sport. The lancet, 2005; 366(1): 33- 34. https://doi.org/10.1016/S0140-6736(05)67838-5

15.Demirhan G. Perception of risk relating to mountain sports. Journal of Physical Education and Sports Training, 2003; 8: 3-10.

16.Humphries D. Injury rates in rock climbers. Journal of Wilderness Medicine, 1993; 4: 281- 285. https://doi.org/10.1580/0953-9859-4.3.281
17.Leaman A, Fitch M. Perception of risk in motor-cyclists. Archives of Emergency Medicine, 1986; 3: 199- 201. https://doi.org/10.1136/emj.3.3.199

18. Martha C, Sanchez X, Gomà-I-Freixanet M. Risk perception as a function of risk exposure among strock climbers. Psychology of Sport and Exercise, 2009; 10: 193- 200. https://doi.org/10.1016/j.psychsport.2008.07.004

19.Palmer C. Death, danger and the selling of risk in adventure sports. In: B. Wheaton editör. Understanding life style sports: Consumption, identity and difference. London: Routledge; 2004. P. 55-69.

20.Zuckerman M. Behavioral expressions and biosocial bases of sensation seeking. Cambridge: Cambridge University Pre; 1994.

21.Zuckerman M. Sensation seeking and risky behavior. Washington, DC: American Psychological Association; 2007. https://doi.org/10.1037/11555-000

22.Ibrahim H, Cordes KA. Outdoor recreation, enrichment for a lifetime. 2nd ed. Sagamore Publishing; 2002.

23.Tholkes B. Defining risk. Camping Magazine, 1998; 71(5): 24-27.

24.Mcdonald MA, Milne RG, Hong JB. Motivational factors for evaluating sport spectator and participant markets. Sport Marketing Quarterly, 2002; 11(2): 100-113.

25.Park H. Analyzing motivational factors of action sports participants, master of arts in education. Washington State University College of Education; 2004.

26.Lopez SJ, O’byrne KK, Petersen S. Profiling courage. In: Lopez SJ, Snyder CR, editors. Positive psychological assessment: A Handbook of Models and Measures, Washington, DC, US: American Psychological Association; 2003. P. 185- 197. https://doi.org/10.1037/10612-012

27.Rinehart RE, Sydnor S. To the extreme: Alternative sports, inside and out. Albany: State University of New York Press, 2003; 407-428.

28.Brymer E, Schweitzer R. Extreme sports are good for your health: A phenomenological understanding of fear and anxiety in extreme sport. Journal of Health Psychology, 2012; 18(4): 477- 487. https://doi.org/10.1177/1359105312446770

29.Zarevski P, Marusic I, Zolotic S, Bunjevac T. Controbition of arnett's inventory of senseation seeking scale to the differentatin of athletes engaged in high and low risk sports. Personality and Individual Differences, 1997; 25(4): 763-768. https://doi.org/10.1016/S0191-8869(98)00119-6

30.Akın A. The development and psychometric characteristics of the self-confidence scala. Abant Izzet Baysal University Education Faculty Magazine, 2007; 7(2): 165-175.

31.Baker T, Simon J. Taking risks: Extreme Sports and the embrace of risk in advanced liberal societies. In: Baker T, Simon J, ed. Embracing Risk: The changing culture of insurance and responsibility. Chicago: University of Chicago Press; 2002. P. 177-208. 
32.Donald RS, Electra DVH, Carolyn SF, Erin R. Thrill seeking: ThetypeTpersonalityandextremesports.InternationalJournal of Sport Management and Marketing, 2007; 1-2(2): 175- 190. https://doi.org/10.1504/IJSMM.2007.011397

33.Breivik G. Personality, sensation seeking and risk taking among Everest climbers. International Journal of Sport Psychology, 1996; 27: 308-320.

34.Robinson V. Taking risks: Identity, masculinities and rock climbing. In: Wheaton B, ed. Understanding life style sports. New York: Routledge; 2004. P. 113-130.

35.Voigt D. Sportsoziologie - Soziologie Des Sports [Sports Sociology - Sociology of Sports]. Frankfurt AM; 1992. (In Deutsch)

36.Delle Fave A, Bassi M, Massimini F. Quality of experience and risk perception in high-altitude climbing. Journal of Applied Sport Psychology, 2003; 15: 82- 98. https://doi.org/10.1080/10413200305402

37.Brymer E. Risk and extreme sports: A Phenomenological Perspective. Annals of Leisure Research, 2010; 13(1-2): 218- 239. https://doi.org/10.1080/11745398.2010.9686845

38.Brymer E, Oades L. Extreme sports: A positive transformation in courage and humility. Journal of Humanistic Psychology, 2009; 49(1): 114- 126. https://doi.org/10.1177/0022167808326199

39. Corbin CB. Sex of subject, sex of opponent, and opponent ability as factors affecting self-confidence in a competitive situation. Journal of Sport Psychology, 1981; 4: 265- 270. https://doi.org/10.1123/jsp.3.4.265

40. Vealey R. Sport-confidence and competitive orientation: An addendum on scoring procedures and gender differences. Journal of Sport and Exercise Psychology, 1988; 10:471- 478. https://doi.org/10.1123/jsep.10.4.471

41. Woodman T, Hardy L. The relative impact of cognitive anxiety and self-confidence upon sport performance: MetaAnalysis. Journal of Sport Sciences, 2003; 21: 443- 457. https://doi.org/10.1080/0264041031000101809

42.Corbin CB, Landers DM, Feltz DL, Senior K. Sex differences in performance estimates: Female lack of confidence vs. maleboastfulness. Research Quarterly for Exercise and Sport, 1983; 54: 407- 410. https://doi.org/10.1080/02701367.1983.10605326

43.Karagun E. Self-confidence level in professional athletes; An examination of exposure to violence, branch and socio-demographic aspects. International Journal of Human Sciences, 2014; 11(2): 744- 753. https://doi.org/10.14687/ijhs.v11i2.3018

44.Jones G, Swain ABJ, Cale A. Ancetedents of multidimensional competitive state anxiety and self confidence in elit intercollegiate middle-distance runners. The Sport Psychologist, 1990, 4: 107- 118. https://doi.org/10.1123/tsp.4.2.107

45.Jones G, Swain, ABJ, Cale A. Gender differences in precompetition temporal pattering and antecedents of anxiety and self confidence. Journal of Sport and Exercise Psychology, 1991; 13: 1- 15. https://doi.org/10.1123/jsep.13.1.1
46.Lirgg CD. Gender differencesin self-confidence in physical activity: A meta- analysis of recent studies. Journal of Sport \& Exercise Psychology, 1991; 13: 294- 310. https://doi.org/10.1123/jsep.13.3.294

47.Jagiełło W, Marina J, Maciej KR, Jan BB, Artur L, Jarosław K. Properties of body composition of female representatives of the Polish national fencing team - the sabre event. Biology of Sport, 2017;34:401-6. https://doi.org/10.5114/biolsport.2017.70526

48.Kalina RM, Jagiełło W. Non-apparatus, Quasi-apparatus and Simulations Tests in Diagnosis Positive Health and Survival Abilities. In: Ahram T, editor. Advances in Human Factors in Sports, Injury Prevention and Outdoor Recreation, vol. 603, Cham: Springer International Publishing; 2018, p. 121-8. https://doi.org/10.1007/978-3-319-60822-8 12

49.Perry JD, Williams JM. Relationship of intensity and direction of competitive trait anxiety to skill level and gender in tennis. The Sport Psychologist, 1998; 12: 169-179. https://doi.org/10.1123/tsp.12.2.169

50.Helsen WF, Starkes JL, Hodges NJ. Team sports and the theory of deliberate practice. Journal of Sport and Exercise Psychology, 1998; 20: 12-34. https://doi.org/10.1123/jsep.20.1.12

51.Hodges NJ, Starkes JL. Wrestling with the nature of expertise: A sport specific test of Ericsson, Krampe and Tesch-Romer's (1993). Theory of "Deliberate Practice." International Journal of Sport Psychology, 1996; 27: 400-424.

52.Starkes JL, Deakin J, Allard F, Hodges NJ, Hayes A. Deliberate practice in sports: What is it anyway? In: Ericsson, $\mathrm{KA}$, ed. The road to excellence: The acquisition of expert performance in the earts and sciences, sports, and games. Mahwah, NJ: Erlbaum; 1996. p. 81-106.

53.Ericsson KA, Charness N, Feltovich PJ, Hoffman RR. The Cambridge handbook of expertise and expert performance. Cambridge, England: Cambridge University Press, 2006. https://doi.org/10.1017/CBO9780511816796

54.George TR. Self-confidence and baseball performance: A causal examination of self-efficacy theory. Journal of Sport and Exercise Psychology, 1994; 16: 381-399. https://doi.org/10.1123/jsep.16.4.381

55.Kitsantas A, Zimmerman BJ. Comparing selfregulatory processes among novice, non-expert, and expert volleyball players: A micro analytic study. Journal of Applied Sport Psychology, 2002; 14: 91-105. https://doi.org/10.1080/10413200252907761

56.Bull SJ, Shambrook CJ, James W, Brooks JE. Towards an Understanding of MentalToughnessinEliteEnglishCricketers. Journal of Applied Sport Psychology, 2005;17:209-27. https://doi.org/10.1080/10413200591010085

57.Jones G, Hanton S, Connaughton D. What is this thing called mental toughness? An investigation of elite sport performers. Journal of Applied Sport Psychology, 2002; 14: 205-218. https://doi.org/10.1080/10413200290103509

58.Mahoney MJ, Gabriel T, Perkıns TS. Psychological skills and exceptional athletic performance. The Sport Psychologist, 1987; 1: 181-199. https://doi.org/10.1123/tsp.1.3.181 


\section{Information about the authors:}

Bostancı Ö.; http://orcid.org/0000-0002-7952-1014; bostanci@omu.edu.tr; Yaşar Doğu Faculty of Sports Sciences, Ondokuz Mayıs University; Ondokuz Mayıs University Kurupelit Campus, 55139 Atakum/Samsun, Turkey.

Karaduman E.; http://orcid.org/0000-0002-7962-315X; karaduman.emre@hotmail.com; Yaşar Doğu Faculty of Sports Sciences, Ondokuz Mayıs University; Ondokuz Mayıs University Kurupelit Campus, 55139 Atakum/Samsun, Turkey.

Mayda M.H.; (Corresponding author); http://orcid.org/0000-0002-7062-3284; hakan.mayda@omu.edu.tr; Yaşar Doğu Faculty of Sports Sciences, Ondokuz Mayıs University; Ondokuz Mayıs University Kurupelit Campus, 55139 Atakum/Samsun, Turkey.

\section{Cite this article as:}

Bostancı Ö, Karaduman E, Mayda MH. Investigation of self confidence levels in elite extreme athletes. Physical education of students, 2019;23(3):106-111.

https://doi.org/10.15561/20755279.2019.0301

This is an Open Access article distributed under the terms of the Creative Commons Attribution License, which permits unrestricted use, distribution, and reproduction in any medium, provided the original work is properly cited http://creativecommons.org/licenses/by/4.0/deed.en

Received: 02.04.2019

Accepted: 04.05.2019; Published: 28.06.2019 